\title{
KONFLIK ANTAR ETNIS MELALUI PENGUATAN WAWASAN MULTIKULTURAL
}

\author{
Hemafitria \\ Program Studi PPKN Fakultas Ilmu Pendidikan dan Pengetahuan Sosial IKIP PGRI Pontianak \\ Jl. Ampera Nomor 88 Pontianak-78116, Telepon (0561) 748219 Fax. (0561) 6589855 \\ Email: rizkyema10@gmail.com
}

\begin{abstract}
Perbedaan dalam suatu masyarakat baik etnis, budaya,agama dan bahasa adalah suatu realita yang harus disikapi secara arif dan bijaksana. Penyikapan ini tentunya bermuara pada terciptanya tatanan masyarakat yang harmonis, rukun dan damai serta jauh dari konflik. Tujuan penelitian ini. Menggali dan mengkaji bentuk implikasi pemahaman wawasan multikultural dalam penanggulangan konflik antar etnis pada masyarakat mempawah. Penelitian ini menggunakan pendekatan kualitatif dengan metode studi kasus di kabupaten mempawah kecamatan Toho. Pendekatan tersebut dianggap tepat untuk kajian penelitian ini, karena fokus penelitian ini adalah kasus yang terjadi dalam kehidupan masyarakat dikecamatan Toho yang disusun dan dibuktikan melalui pengumpulan data yang sistematis, dan analisis data yang berkenaan dengan fenomena itu. Teknik analisis data yang digunakan dalam penelitian ini terdiri atas tiga alur kegiatan yang terjadi secara bersamaan yaitu reduksi data, penyajian data, penarikan kesimpulan/verifikasi. Berdasarkan hasil temuan bahwa pengembangan wawasan multikultural dalam masyarakat Mempawah yang melibatkan seluruh komponen yang ada mulai dari masyarakat itu sendiri, tokoh masyarakat dan agama, sekolah serta pihak pemerintah dirasakan pentingnya dalam konteks masyarakat mempawah untuk mencegah terjadinya konflik. Untuk itu perlu dilakukan tiga bentuk penguatan yaitu berorientasi pada pembauran atau interaksi sosial yang ditandai dengan upaya menciptakan komunikasi yang baik, berorientasi kerja sama antar umat beragama dan berorientasi sikap toleransi dan menghormati.
\end{abstract}

Kata Kunci: konflik multietnis, wawasan multikultural

\begin{abstract}
Differences, between people with good culture, religion and language are realities that must be addressed and questioned. This attitude certainly leads to the creation of a harmonious, harmonious and peaceful society and away from conflict. The purpose of this study. Exploring and examining the implications of understanding multicultural insights in tackling inter-ethnic conflict in the Mempawah communities. This study used a qualitative approach with a case study method in the district under Toho sub-district. This approach is considered appropriate for the study of this study, because the focus of this research is cases that occur in the lives of people in the Toho sub-district that are compiled and proven through systematic data collection, and data analysis relating to that phenomenon. The data analysis technique used in this study consists of three lines of activities that occur simultaneously namely data reduction, data presentation, conclusion drawing / verification. Based on the findings that the development of multicultural insights in Mempawah society involving all components starting from the community itself, community and religious leaders, schools and the government were felt to be important in the context of the community to prevent conflict. For this reason, it is necessary to do three forms of reinforcement, which are oriented to intermingling or social interaction which is characterized by efforts to create good communication, cooperation oriented among religious people and oriented towards tolerance and respect.
\end{abstract}

Keywords: multiethnic conflict, multicultural insight

\section{PENDAHULUAN}

Kenyataan yang tak dapat ditolak bahwa masyarakat dan bangsa Indonesia terdiri atas berbagai keragaman sosial, kelompok etnis, budaya, agama, aspirasi politik dan lain-lain sehingga "masyarakat dan bangsa Indonesia secara sederhana dapat disebut sebagai masyarakat "multikultural". Keragaman ini diakui atau tidak, akan menimbulkan bebagai persoalan seperti yang sekarang dihadapi bangsa ini. 
Keragaman budaya juga berpotensi untuk menimbulkan konflik yang dapat mengancam integrasi bangsa. Karena konflik antar budaya dapat menimbulkan pertikaian antar etnis, antar penganut agama, ras maupun antar golongan yang bersifat sangat sensitif dan rapuh terhadap suatu keadaan yang menjurus ke arah dis-integrasi bangsa. Fenomena ini dapat terjadi, apabila konflik tersebut tidak dikendalikan dan diselesaikan secara arif dan bijaksana oleh pemerintah bersama seluruh komponen anak bangsa (Najwan, 2009).

Secara historis diketahui Kalimantan Barat telah mengalami konflik yang melibatkan komunitas dari etnis yang berbeda; misalnya peristiwa 1950 yaitu perkelahian antara orangorang Madura dengan Dayak, pada tahun 1967 terjadi kerusuhan sosial yang melibatkan orang Dayak dengan Cina. Tahun 1979 kerusuhan antara Madura dengan Dayak di Samalantan, tahun 1983 konflik Madura dengan Dayak, tahun 1997 terjadi konflik antara orang Madura dengan Dayak di Sanggau Ledo Sambas (Saad, 2000: 3; Bamualim, Chaidir.S. dkk ed. 2002; Fatmawati, 2011, Mochtar, 2007). Kemudian, di akhir tahun 1999 dan awal tahun 2000 terjadi kerusuhan besar lagi antara orang Madura dengan orang Melayu di Sambas, yang kemudian juga diduga melibatkan orang-orang Dayak yang membantu orang Melayu (al-Qadrie, 2003: 108).

Konflik etnik merupakan salah satu jenis konflik yang tujuan dari salah satu pihak secara khusus didefinisikan dalam kerangka etnik, dan dimana kesalahan utama dari konfrontasi tersebut adalah perbedaan etnik. Apapun isu yang nyata ketika konflik terjadi, paling tidak, salah satu pihak yang bertikai akan menjelaskan kekecewaanya dalam istilah-istilah etnis, salah satu pihak yang bertikai akan mengklaim bahwa perbedaan identitas etnik adalah alasan kenapa anggota etnis tidak dapat menyadari keinginannya, mengapa mereka tidak memperoleh hak yang sama, atau mengapa klaim mereka tidak memuaskan (Stefan Wolf, 2006)

Berdasarkan fakta yang dikemukakan tersebut, sejarah konflik antaretnik di Kalimantan Barat merupakan suatu sejarah yang panjang yang berulang- ulang. Peristiwa dan isu konflik tersebut telah mendapatkan perhatian dari berbagai pihak. Munculnya wacana multikultural merupakan reaksi terhadap perhatian konflik etnis dengan adanya pluralitas yang begitu kompleks di dalam masyarakat, yang didalamnya tidak hanya pengakuan yang dibutuhkan, tetapi juga kesadaran budaya yang inklusif dan transformatif. Suparlan (2005:98) menyatakan Multikulturalisme dikembangkan dari konsep pluralisme budaya (culture pluralism) dengan menekankan kesederajatan-kebudayaan yang ada dalam sebuah masyarakat. Pluralisme merupakan ideologi yang berkembang pada masyarakat plural (plural society).

Prinsip-prinsip dasar multikultural mengakui dan menghargai keberagaman kelompok masyarakat seperti etnik, ras, budaya, gender, strata sosial, agama, perbedaan kepentingan, keinginan, visi, keyakinan dan tradisi yang akan sangat membantu bagi terwujudnya perubahan 
prilaku yang kondusif dan sangat menjanjikan di tengah kehidupan masyarakat dan bangsa yang majemuk. Dengan demikian pendekatan multikultural tidak sesungguhnya berlandaskan pada kepemilikan yang mengisyaratkan pada memiliki atau dimiliki budaya tertentu tetapi berlandaskan pada kesadaran untuk menghargai dan menghormati.

Wawasan multikultural merupakan suatu paham tentang penghargaan, dan keadilan terhadap etnik minoritas baik yang menyangkut hak-hak universal yang melekat pada hak-hak individu maupun hak-hak komunitasnya yang bersifat kolektif dalam mengekspresikan budayanya. Jadi pada dasarnya multikultural merupakan gagasan yang mengatur keberagaman dengan prinsip dasar pengakuan akan keberagaman itu sendiri.

Jadi, berangkat dari paparan argumentasi di atas, bahwa ketidakmampuan memahami perbedaan dalam etnik di luar dirinya yang dapat berakibat terjadinya konflik sehingga penguatan akan wawasan multikultural dalam rangka terciptanya masyarakat yang terbuka terhadap segala keragaman berbagai aspek dalam kehidupan.

\section{METODE}

Pendekatan yang digunakan dalam penelitian tentang Penanggulangan konflik antar etnis melalui penguatan wawasan multikultural adalah pendekatan kualitatif, yaitu pendekatan yang tidak menggunakan perhitungan-perhitungan secara sistematis dan statistik, melainkan lebih menekankan pada kajian interpretatif. Pendekatan penelitian kualitatif disebut juga pendekatan naturalistic karena situasi lapangan penelitian bersifat natural atau alamiah, apa adanya, dan tidak dimanipulasi (Cresswell, 1998). Metode yang digunakan adalah Studi kasus, atau penelitian kasus (case study), adalah penelitian tentang situs penelitian yang berkenaan dengan suatu fase spesifik atau khas dari keseluruhan personalitas (Maxfield). Studi kasus, atau penelitian kasus (case study) merupakan metode penelitian ilmu sosial yang sangat cocok di gunakan manakala peneliti ingin mengungkapkan sesuatu yang bertolak pada pertanyaan "how" atau "why", bila peneliti hanya memiliki sedikit peluang untuk mengontrol peristiwa-peristiwa yang akan diselidiki dan bilamana fokus penelitiannnya terletak pada fenomena kontemporer (masa kini) di dalam konteks kehidupan nyata (Robert K. Yin, 2002:1). Penelitian ini menyelidiki secara langsung kehidupan masyarakat Mempawah khususnya kecamatan Toho berdasarkan sejarah konflik yang pernah terjadi.

Teknik pengumpulan data yang digunakan dalam penelitian ini adalah observasi partisipatif, wawancara mendalam, dokumentasi, triangulasi dan studi literature (Sugiono, 2011: 25). Sementara iyu analisis data yang digunakan dalam penelitian ini adalah reduksi data, display data, verifikasi/ penarikan kesimpulan (Miles dan Huberman, 2007). 


\section{HASIL DAN PEMBAHASAN}

\section{Pemahaman wawasan multikultural masyarakat kecamatan Mempawah}

Pemahaman wawasan multikultural masyarakat Toho yang terdiri dari karakteristik masyarakat yang majemuk telah terkonsepkan secara baik dengan saling memahami, menjaga kebersamaan serta adanya pembauran hidup dalam satu wilayah. Hal ini telah diungkapkan melalui deskripsi hasil penelitian menurut Samsi Ali (63 thn) menyatakan masyarakat Mempawah telah memiliki pemahaman wawasan multukultural sebagai suatu pengetahuan tentang budaya yang ada yang harus dipahami sebagai suatu keniscayaan yang melahirkan sikap menghargai, menghormati, toleransi dan tidak dipungkiri pula dalam perbedaan tersebut akan menimbulkan gesekan atu persinggunggun.

Pemahaman wawasan multikultural masyarakat Mempawah dapat dilihat dari keterlibatan dalam beberapa kegiatan yang mampu diaktualisasikan secara positif, yakni dengan melakukan gotong royong serta adanya pembauran hidup secara turun-temurun yang sudah lama berlangsung. Hal ini tentunya dapat mendorong warga masyarakat melakukan pengamalan nilainilai kebaikan yang bersumber dari ajaran budaya dan agama dalam kehidupan sehari-hari seperti kejujuran, salaing percaya, menghargai, menghormati, tenggang rasa, tolong menolong dan bekerjasama dalam menyelesaikan berbagai permasalahan dan kepentingan bersama.

Hal itu tercermin dalam ungkapan Azra (2006:154) bahwa Multikulturalisme ini mengusung semangat untuk hidup berdampingan secara damai (peaceful coexistence) dalam perbedaan kultur yang ada baik secara individual maupun secara kelompok dan masyarakat. Idividu dalam hal ini dilihat sebagai refleksi dari kesatuan sosial dan budaya di mana mereka menjadi bagian darinya dengan demikian, corak masyarakat Indonesia yang berbinneka tunggal ika bukan lagi keanekaragaman suku bangsa dan kebudayaannya tetapi keanekaragaman kebudayaan yang ada dalam masyarakat Indonesia.

Faktor lain yang dapat diungkap dalam kehidupan masyarakat Mempawah ialah memegang teguh pendirian budaya oleh masyarakat Mempawah yang dapat membawa pengaruh terhadap kerukunan antar umat beragama. Sementara adaptasi dan asimilasi budaya merupakan bentuk dari pemahaman multikultural masyarakat Mempawah. Melalui adaptasi akan ada proses penyesuaian nilai, norma dan pola-pola prilaku. Proses asimilasi itu ditandai oleh pengembangan sikap-sikap yang sama yang walaupun terkadang bersifat emosional, bertujuan untuk mencapai kesatuan, atau paling sedikit untuk mencapai integrasi dalam organisasi dan tindakan (Soejono Soekamto 1993:137).

Menurut hasil temuan penelitian bentuk penghargaan dalam pemahaman wawasan multikultural dalam masyarakat Mempawah sifatnya alamiah, apa adanya. Hal ini dapat 
dibuktikan dengan adanya sikap menerima yang dilakukan oleh etnis atau suku asli terhadap etnis pendatang. Sikap menerima yang dimiliki oleh masyarakat melahirkan suatu akibat positif dari proses interaksi yang cukup intensif yaitu adanya pertukaran bahasa antaretnis, memahami keyakinan yang ada pada sebagian masyarakat melalui berbagai kegiatan seperti pernikahan dan kematian.

Dengan demikian aspek multi budaya dan etnis maupun multi agama menampakkan adanya kerukunan dalam masyarakat Mempawah. Konsep pengembangan wawasan multikultural dijelaskan dengan pengakuan akan keanekaragaman sebagai suatu yang melekat pada diri seseorang yang harus dihormati orang lain dan bukan merupakan sesautu yang dipaksakan.

Kehidupan masyarakat multikultural tidak selamanya berjalan harmonis dalam tata pergaulannya. Potensi-potensi yang membuat disharmonis dapat terjadi kapanpun. Ini adalah konsekuensi logis dari sebuah masyarakat yang majemuk. Peneliti di sini mengidentifikasi beberapa hal yang berpeluang atau berpotensi dapat mempengaruhi kerukunan dan keharmonisan masyarakat Mempawah. Hal ini juga diungkap oleh salah satu responden (Basuki, 55 th, desa pak laheng) memberikan pandangannya bahwa etnis Madura dan Dayak keduanya mempunyai sifat yang sama menonjolkan sifat kesukuan, dendam dan emosional. Bahkan etnis lainnya seperti Jawa dan Melayu yang merupakan pendatang lebih memilih sikap mengalah atau pengalah ketika ada persoalan demi menghindari konflik.

Begitu juga keterangan kepala desa Sambora Bapak Efendi, ia menilai masyarakat mulai kritis, berani membuat mosi tidak percaya seperti yang ditujukan dan dialami pada dirinya. Ada sikap kontrol sosial yang tidak tepat untuk tidak mengatakan tidak bijak dilakukan oleh sebagian masyarakat. Yakni, penolakan terhadap kebijakan kepala desa dengan tidak mengetahui persoalan sesungguhnya yang berefek negatif terhadap harmonisasi pemimpin dengan yang dipimpin bahkan terhadap sesama yang dipimpin, yakni sesama anggota masyarakat.

Berdasarkan beberapa keterangan di atas, peneliti menilai bahwa pada satu sisi masyarakat Mempawah memang menyimpan beberapa potensi konflik - bahkan pada sebagian masyarakat masih belum bisa menerima keberadaan etnis tertentu. Meskipun pada lainnya terdapat lapisan permukaan yang relatif rukun dan damai. Untuk itu diperlukan sikap arif dan bijak dalam mensiasati setiap persoalan yang terjadi agar konflik dapat diminimalisir dan diantisipasi untuk tidak terjadi.

Pemahaman akan wawasan multikultural ini merupakan suatu bentuk terpadu dari suatu kemajemukan masyarakat untuk saling memahami dan menghormati atas budaya seseorang.. Senada dengan pendapat ini Suparlan (2004:3) mengungkapkan pemahaman tentang multikulturalisme menjelaskan bahwa akar dari kata multikulturalisme adalah kebudayaan. 
Multikulturalisme adalah sebuah idiologi dan sebuah alat atau wahana untuk meningkatkan derajat manusia dan kemanusiaannya, maka konsep kebudayaan harus di lihat dalam perspektif fungsinya bagi kehidupan manusia. Pasurdi Suparlan mengkaji sebagai sebuah ide atau idiologi multikulturalisme terserap dalam berbagai interaksi yang ada dalam berbagai struktur kegiatan kehidupan manusia yang tercakup dalam kehidupan ekonomi, bisnis dan kehidupan politik, dan berbagai kegiatan lainnya di dalam masyarakat yang bersangkutan.

\section{Potensi Konflik antar etnis merupakan hambatan dalam Masyarakat Multikultural}

Keharmonisan yang dikembangkan dalam masyarakat Kabupaten mempawah yang terdiri dari berbagai perbedaan tetap memiliki sejumlah potensi konflik dalam hubungan etnis. Konflik adalah " situation in which people, groups, or countries are involved in a serious disagreement or argument". Sementara itu kekerasan adalah "violent behaviour that is intended to hurt or kill”. (Oxford Dictionary, 2003). Dengan demikian konflik, dalam berbagai jenisnya adalah peristiwa sosial yang lumrah terjadi. Yang paling penting adalah bagaimana mengelola konflik agar tidak menjelma menjadi sebuah kekerasan.

Peneliti mengidentifikasi beberapa hal yang memberikan kontribusi potensi konflik , yaitu Kebencian Sosial Budaya Terselubung (Social-cultural animocity) seperti: Pertama, Penerapan hukum adat dayak terhadap semua etnis. Menurut sebagian masyarakat menilai bahwa hukum adat di sisi positif memang mampu memberikan kontrol bagi masyarakat. Namun, sisi negatifnya ada upaya pemaksaan adat etnis tertentu terhadap etnis yang lain. Hukum adat dayak ternyata harus dipatuhi oleh semua etnis yang ada. Terlepas diterima atau tidak terima, suka atau tidak suka dengan hukum adat dayak namun hukum adat tersebut tetap diberlakukan bagi semua etnis yang ada di kabupaten Mempawah. Dengan penerapan hukum adat seperti itu hukum adat menjadi tidak natural atau terkesan dipaksakan. Jika hal ini terus-menerus menjadi pertanyaan yang membayangi setiap aktivitas keseharian mereka, maka tidak mustahil justru hukum adat tersebut berpeluang melahirkan konflik baru nantinya.

Kedua, Terdapat sebagian warga yang memelihara binatang (tidak dikandang) yang oleh sebagian yang lain dianggap tidak baik bahkan mengharamkannya dan membiarkan berkeliaran di sekitar tempat tinggal bahkan tempat ibadah dikhawatirkan dapat memicu ketidakrukunan antar warga.

Ketiga, Realitas kerukunan masyarakat mempawah akan terusik jika di dalam diri mereka sendiri muncul pemikiran pengkotakan antara suku pendatang dan suku asli. Suku pendatang adalah mereka di luar etnis dayak, seperti melayu, jawa, batak bugis, cina dan sebagian kecil madura. Sementara suku asli adalah mereka yang beretnis dayak. Dengan kata lain, ada semacam 
dikotomi antara suku asli dan suku pendatang. Suku pendatang adalah subdominant suku asli, yang dianggap sebagai pelengkap. Jika hal ini terus dirasakan atau tumbuh subur pada diri sebagian masyarakat Mempawah, maka bukan hanya potensi konflik yang muncul namun menjadikan masyarakat itu sendiri tidak berkembang. Kemajuan masyarakat hanya menjadi harapan belaka, tidak terwujud. Karena masyarakat yang sehat pola interaksinya adalah terjalinnya kerja sama antar warga tanpa ada prasangka dan curiga yang disebabkan eksklusifitas kesukuan. Salah satu indikator dari titik isu dalam konflik adalah anggota dari komunitas yang berbeda dan atau anggota lain di dalam kelompok yang sama mempunyai konsepsi yang berbeda terhadap sebab-sebab konflik yang sebenarnya (Zakiya, 2017).

Keempat, Adanya sifat pengalah pada etnis pendatang. Sifat pengalah atau mengalah pada sisi tertentu sebenarnya sangat positif karena di dalamnya ada nilai-nilai kesabaran dan upaya untuk menahan diri agar tidak terjebak oleh emosional pribadi dan kelompok. Sifat ini lebih banyak menilai ke dalam dirinya daripada menilai di luar dirinya ketika memandang suatu peristiwa yang terjadi. Sementara di sisi lain sifat ini justru dianggap negatif karena disalah tafsirkan sebagai sifat penakut. Namun jika sifat ini terus terakumulasi sedemikian lama dan membesar, maka tidak mustahil akan mencuat ke permukaan menjadi konflik Jadi hal ini yang perlu disikapi secara arif dan bijak oleh pemuka dan tokoh masyarakat Mempawah.

Senada dangan hal ini Budimansyah dan Suryadi (2008:9) menyatakan sumber terjadinya berbagai gejolak dalam masyarakat kita saat ini adalah akibat munculnya kebencian sosial budaya terselubung. konflik budaya terselubung ini bersifat laten karena terdapat mekanisme sosialisasi kebencian yang berlangsung hampir seluruh pranata sosialisasi dimasyarakat mulai dari keluarga, sekolah, kampung, tempat ibadah, media massa, organisasi massa, organisasi politik dan sebagainya.

\section{Upaya pengembangan wawasan multikultural dalam penanggulangan konflik antar etnis}

Implikasi pemahaman wawasan multikultural masyarakat Mempawah ternyata berpengaruh terhadap terciptanya kerukunan antar etnik. Adapun pengaruh tersebut berdasarkan penelitian menempati berapa bentuk yaitu interaksi Sosial, kerjasama dan toleransi.

\section{a. Interaksi Sosial}

Kehidupan bangsa yang multikultural hendaknya memberikan peluang yang sama (tidak diskriminatif) kepada seluruh warga negara, dengan memberikan penghhargaan terhadap keragaman (etnik, budaya dan agama), untuk tujuan mempererat, merekatkan serta memperkuat persatun dan kesatuan bangsa. Afif (2008:6) menyatakan pada hakekatnya dalam setiap budaya dan agama terdapat nilai-nilai yang mengajarkan kebaikan dan mendorong manusia untuk 
berbuat kebajikan. Oleh karena itu diperlukan perencanaan sosial yang matang dalam mengantarkan bangsa Indonesia yang multikultur ke dalam proses interaksi sosial.

Menurut Muslim (2013) interaksi sosial menyangkut hubungan timbal balik antarpribadi, kelompok, maupun pribadi dengan kelompok. Hal ini tercermin dalam aktivitas-aktivitas sosial yang mampu dilakukan oleh masyarakat Toho dengan karakteristik perbedaan yang ada. Interaksi itu tidak hanya dipicu oleh dorongan kebutuhan ekonomis, biologis, emosional dan sebagainya yang mengikat dirinya, melainkan juga sebagai fitrah yang tak terbantahkan pada dirinya (Husain 1993: 78).

Interaksi sosial yang meliputi pembauran dan komunikasi antar etnis dan agama sudah tampak pada masyarakat Mempawah. Interaksi sosial dapat terjadi karena adanya kontak sosial dan komunikasi. Anggota Masyarakat berinteraksi antar sesama dan dengan kelompok lain berdasarkan pengetahuan dan pemahaman terhadap norma yang berlaku dalam kehidupan masyarakat.

Membangun interaksi sosial positif yang didasari semangat multikultural yang dimiliki masyarakat Mempawah, tidak cukup dengan sikap mengakui dan menerima kenyataan masyarakat yang majemuk tetapi harus disertai dengan sikap yang tulus untuk menerima kemajemukan itu sebagai suatu hal yang bernilai positif dan merupakan rahmat Tuhan kepada manusia.

Berdasarkan adanya interaksi sosial yang dimiliki masyarakat Mempawah menunjukan bahwa identitas diri yang dimiliki tidak semata-mata ditujukan oleh apa yang kita miliki, tetapi ditentukan pula oleh pengakuan semua orang atau sekelompok lain terhadap kita dalam situasi tertentu. Hal inilah yang seharusnya dimiliki oleh masyarakat Mempawah dalam megembangkan wawasan multikultural agar terciptanya kerukunan antarumat beragama.

\section{b. Kerja sama}

Kerja sama bisa terjadi bila individu atau kelompok mempunyai kesadaran akan tujuan yang sama, sehingga timbul aktivitas yang salling menunjang membantu untuk bersama-sama mencapai tujuan. Bentuk kerja sama yang dapat diwujudkan oleh masyarakat Mempawah melalui arisan gawai atau arisan perkawinan, arisan sunatan, arisan kematian, belalik, dan gotong-royong.

Bentuk kerja sama difungsikan sebagai perekat sosial, sebagai modal sosial dan memperkokoh modal sosial. Melalui kegiatan arisan gawai atau arisan perkawinan, arisan sunatan, arisan kematian, belalik, dan gotong-royong akan terjadi integrasi antar orang-orang dari berbagai kelas sosial dan agama serta beragam latar belakang. Tradisi tersebut dapat dikontektualisasikan pada masyarakat yang lebih luas, yakni tidak terbatas pada satu kampung 
atau satu desa. Namun tradisi tadi dapat juga diterapkan pada masyarakat bangsa, yakni bagaimana setiap penduduk negeri ini memiliki rasa tanggung jawab dan jiwa menolong sehingga tidak akan ada lagi pertikaian ataupun permusuhan di antara masyarakat yang berbeda. Setiap bentuk kerja sama, belalik misalnya akan berkumpul sekelompok orang dari komunitas mereka, maka orang-orang yang terlibat dalam kegiatan akan menyadari akan keberadaan kelompok mereka dengan segala identitasnya.

\section{c. Toleransi}

Keindahan kerukunan Umat beragama akan tercipta jika masyarakat mampu menciptakan sikap toleransi. Toleransi adalah sikap dan prilaku manusiawi dan religius, yang tidak hanya menghormati perbedaan, tetapi juga menjunjung tinggi kebebasan setiap pribadi dalam menentukan jalan hidupnya sejauh tidak melanggar norma-norma sosial. Dalam konsep toleransi ini, istilah menerima dipahami sebagai menghormati dan mengakomodasi fakta perbedaan menjadi suatu kekuatan positif bagi terciptanya keharmonisan ( Lauster, 1994:84).

Sejalan dengan pendapat diatas Masykuri Faridah (2013) menyatakan toleransi beragama, sikap demokrasi dalam masyarakat plurarl sangat penting, oleh sebab itu, penting meningkatkan toleransi, yang antara lain, melalui kepercayaan diri. Orang yang tingkat toleransinya tinggi atau sudah mencapai taraf kebijaksanaan dapat menyadari bahwa perbedaan pendapat (etnik, agama dan lain-lain), bukanlah sesuatu yang yang ditakutkan, tetapi fenomena yang wajar dalam konteks interaksi. Kesadaran ini penting sebab memuat sikap dan prilaku toleransi mudah dikembangkan..

Hasil penelitian menyatakan sikap toleransi yang telah diwujudkan dalam kehidupan masyarakat Mempawah dapat dilihat dalam bentuk menghormati agama dan kepercayaan orang lain yang diwujudkan dengan kebebasan melaksanakan ajaran dan agama masing-masing. Sikap ini tentunya mendorong masyarakat Toho dalam mengikuti perayaan hari besar keagamaan seperti perayaan natal bersama dan halal bil halal bersama.

Berdasarkan telaah atas data lapangan dan pembahasan realitas kerukunan seperti di muka, dapatlah dikatakan bahwa wawasan multikultural pada masyarakat Mempawah telah membawa pengaruh terhadap kerukunan antar etnik. Oleh karena itu peneliti mengelaborasikan kembali bahwa wawasan multikultural masyarakat Toho telah berimplikasi positif terhadap kerukunan antar umat beragama dengan karakter yang dapat dibanggakan seperti, Masyarakat Toho mampu menerima adanya kemajemukan umat beragama, Sikap toleran terhadap umat beragama telah diekspresikan dalam ruang privat masing-masing, Tenggang rasa dalam mengekspresikan diri sehingga tidak mengganggu ruang privat lain dan tidak mengganggu ruang publik, Hormat-menghormati dan menjalin hubungan baik serta bekerja sama intern dan ekstern 
antar ruang privat, dengan kata lain menjalin kerukunan umat beragama, Bersungguh-sungguh memaknai kemajemukan dan kekayaan religius dalam upaya mengisi nilai-nilai dasar dan kearifan lokal yang dimiliki masyarakat Mempawa dalam harmonisasi pergaulan masyarakat.

\section{SIMPULAN}

Berdasarkan hasil pembahasan dapat disimpulan bahwa realitas pemahaman multikultural masyarakat Mempawah telah terkonsepkan secara baik dengan adanya saling memahami, menghormati, menghargai perbedaan dan keterlibatan dalam beberapa kegiatan seperti gawai, belalik dan lainnya serta adanya pembauran hidup secara turun-temurun yang sudah berlangsung lama yang mengakibatkan terjadinya adaptasi dan asimilasi budaya serta ditambah upaya memegang teguh nilai budaya luhur atau kearifan lokal.

Kebencian Sosial Budaya Terselubung (Social-cultural animocity) yang diyakini memberikan pengaruh dalam menjalin hubungan harmonis serta berpotensi terjadinya konflik dalam masyarakat Mempawah dapat dilhat melalui penerapan hukum adat dayak dinilai kurang proporsional karena diberlakukan untuk semua etnis, Memelihara binatang yang tidak dikandangkan, pengkotakan antara suku pendatang dan suku asli yang berimplikasi terhadap adanya rasa ketidakadilan dalam pembagian peran di masyarakat.

Secara konseptual Implikasi pemahaman multikultural yakni dapat dilihat melalui aktualitas dari pemahamannya menempati bentuk pertama, Interaksi sosial yang meliputi pembauran dan komunikasi antar etnis dan agama. kedua, Kerjasama seperti arisan gawai atau arisan kematian, belalik, dan gotong-royong yang miliki fungsi sebagai perekat sosial, sebagai modal sosial dan dapat berfungsi memperkokoh identitas kelompok melalui suatu momen khusus. Ketiga, Sikap Toleransi menghormati agama dan kepercayaan orang lain yang diwujudkan dengan kebebasan melaksanakan ajaran dan agama masing-masing dan perayaan natal bersama, halal bil halal bersama.

\section{DAFTAR PUSTAKA}

Al-qadrie. (2003) Konflik Komunal di Indonesia Saat Ini (Terj. Suaisi Asy'ari) Jakarta: INIS.

Azra, A. (2006). "Pancasila dan Identitas Nasional Indonesia Perspektif Multikulturalisme". Dalam Restorasi Pancasila: Mendamaikan Politik Identitas dan Modernitas. Bogor: Brigten Press.

Bamualim, Chaidir.S. dkk (ed). 2002. Communal Conflicts in Contemporary Indonesia. Jakarta: Pusat Bahasa IAIN Syarif Hidayatullah dan The Konrad Adenaeur Foundation

Budimasyah,D dan Karim Suryadi. (2008) PKn dan Masyarakat Multikultur. Bandung: Program Studi Pendidikan Kewarganegaraan SPs UPI.

Creswell, W.J (1998). Qualitative Inquiry And Research Design: Choosing Among Five Tradition. California:Thousand Oask. 
Faridah (2013). Tolerasi Antarumat beragama Masyarakat Perumahan. Jurnal Komunitas. Vol 5, No 1 (2013).

Fatmawati. 2011. Harmonisasi Antar Etnik di Kalimantan Barat, Studi Ethnografi MelayuDayak. Pontianak: STAIN Pontianak Press.

Husain (1993). Fikh Hubungan Antar Agama. Jakarta: Ciputat Press, 1993.

Miles,M.B \& Huberman, M. (1992). Analisis Data Kualitatif: Buku Sumber.

Mochtar, Zulfidar Zaidar. 2007. Mediasai Melayu-Madura. Pontianak: Romeo Mitra Grafika.

Muslim (2013). Interaksi Sosial dalam Masyarakat Multietnis Jurnal Diskursus Islam Volume 1 Nomor 3, Desember 2013

Najwan (2009). Konflik Antar Budaya dan Antar Etnis di Indonesia Serta Alternatif Penyelesaiannya. Jurnal Hukum No. Edisi Khusus Vol. 16 Oktober 2009: 195 - 208.

Saad, Munawar M. 2003. Sejarah Konflik antar Suku di Kabupaten Sambas. Pontianak: Kalimantan Persada Press

Sugiono (2011). Metode Penelitian Kombinasi. Bandung: Alfabeta.

Suparlan, P. (2005). Sukubangsa dan Hubungan Antar Sukubangsa. Jakarta: Yayasan Pengembangan Kajian Ilmu Kepolisian.

Yin, Robert K. (2002). Case Study Research: Desing and Methods (Applied Social Research Methods). Illinois: Sage Publications, Inc.

Zakiyah, (2017). Cendikiwan Muslim dan Wacana Konflik Etnis di Kalimantan Barat. PANANGKARAN, Jurnal Penelitian Agama dan Masyarakat. Volume 1, Nomor 2, JuliDesember 2017 